\title{
Shewanella marina sp. nov., isolated from seawater
}

Correspondence
Chi Nam Seong
scnu@scnu.ac.kr

\author{
Seong Chan Park, ${ }^{1}$ Keun Sik Baik, ${ }^{1}$ Mi Sun Kim, ${ }^{1}$ Duwoon Kim ${ }^{2}$ \\ and Chi Nam Seong ${ }^{1}$
}

\author{
${ }^{1}$ Department of Biology, Sunchon National University, Suncheon 540-742, Republic of Korea \\ ${ }^{2}$ Division of Food Science and Aqualife Medicine, Chonnam National University, Yeosu 550-749, \\ Republic of Korea
}

\begin{abstract}
A motile, rod-shaped, pale-brown-pigmented bacterium, designated strain $\mathrm{C}^{\top}{ }^{\top}$, was isolated from seawater collected from the South Sea (Republic of Korea). Cells were Gram-negative, facultatively anaerobic, and catalase- and oxidase-positive. The major fatty acids were summed feature $3\left(\mathrm{C}_{16: 1} \omega 7 c\right.$ and/or iso- $\left.\mathrm{C}_{15: 0} 2-\mathrm{OH} ; 19.4 \%\right), \mathrm{C}_{16: 0}(16.3 \%), \mathrm{C}_{17: 1} \omega 8 c(9.5 \%)$ and iso- $\mathrm{C}_{15: 0}(7.7 \%)$. The DNA G $+\mathrm{C}$ content was $40.8 \mathrm{~mol} \%$. A phylogenetic tree based on $16 \mathrm{~S}$ rRNA gene sequences showed that strain $\mathrm{C} 4{ }^{\top}$ formed a lineage within the genus Shewanella (92.7-96.1\% sequence similarity to representative strains of the genus Shewanella) and was part of a distinct branch with the clade comprising Shewanella haliotis DW01 ${ }^{\top}$ and Shewanella algae ATCC $51192^{\top}$. Phenotypic characteristics enabled strain $\mathrm{C} 4^{\top}$ to be distinguished from $S$. haliotis and $S$. algae. On the basis of the data presented in this study, strain $\mathrm{C} 4^{\top}$ represents a novel species, for which the name Shewanella marina sp. nov. is proposed. The type strain is $\mathrm{C} 4^{\top}$ $\left(=\right.$ KCTC $22185^{\top}=$ JCM $\left.15074^{\top}\right)$.
\end{abstract}

The genus Shewanella is a member of the class Gammaproteobacteria (Anzai et al., 2000) and comprises a group of Gram-negative, motile, rod-shaped, oxidasepositive, non-fermentative and facultatively anaerobic aquatic and marine bacteria (Bowman, 2005; Gauthier et al., 1995; MacDonell \& Colwell, 1985; Venkateswaran et al., 1999). At the time of writing, the genus Shewanella comprised 47 recognized species (http://www.bacterio. cict.fr/s/shewanella.html). Strains of the genus Shewanella have been isolated from a variety of sources, i.e. marine environments including seawater, sediment, invertebrates and fish (Bowman et al., 1997; Bozal et al., 2002; Brettar et al., 2002; Gao et al., 2006; Gram et al., 1987; Gram \& Huss, 1996; Hirota et al., 2005; Ivanova et al., 2001, 2003a, b, 2004a, b; Kim et al., 2007; Lee et al., 2006; Leonardo et al., 1999; Makemson et al., 1997; Miyazaki et al., 2006; Myers \& Nealson, 1988; Nealson et al., 1991; Nogi et al., 1998; Satomi et al., 2003, 2006, 2007; Simidu et al., 1990; Skerratt et al., 2002; Stenström \& Molin, 1990; Toffin et al., 2004; Venkateswaran et al., 1998, 1999; Xiao et al., 2007; Yang et al., 2006, 2007; Yoon et al., 2004a, b; Ziemke et al., 1998; Zhao et al., 2005, 2006, 2007), clinical samples (Brink et al., 1995; Debois et al., 1975; Holmes et al., 1975; Levin, 1972; Nozue et al., 1992), oilfield fluids (Semple \& Westlake, 1987) and activated sludge (Xu et al., 2005).

The GenBank/EMBL/DDBJ accession number for the 16S rRNA gene sequence of strain $C 4^{\top}$ is EU290154.

A scanning electron micrograph and GN2 MicroPlate (Biolog) data for strain $\mathrm{C}^{\top}{ }^{\top}$ are available as supplementary material with the online version of this paper.
Members of this genus are known to play important roles in co-metabolic bioremediation of halogenated organic pollutants (Petrovskis et al., 1994), destruction of crude petroleum (Semple \& Westlake, 1987), the dissimilatory reduction of manganese and iron oxides (Myers \& Nealson, 1988) and production of high proportions of polyunsaturated fatty acids (Russell \& Nichols, 1999). They have also been implicated as opportunistic pathogens of humans and aquatic animals (Aguirre et al., 1994; Brink et al., 1995) and as the causal agents of proteinaceous food spoilage (Jørgensen \& Huss, 1989).

In the course of our study on the microbial diversity of seawater, a rod-shaped bacterial strain, designated $\mathrm{C} 4^{\mathrm{T}}$, was isolated and was the subject of a taxonomic investigation. On the basis of evidence from polyphasic taxonomic studies, strain $\mathrm{C}^{\mathrm{T}}$ is considered to represent a novel species in the genus Shewanella.

Strain $\mathrm{C}^{\mathrm{T}}$ was isolated from seawater collected from the South Sea near Gwangyang $\left(34^{\circ} 51^{\prime} \mathrm{N} 128^{\circ} 47^{\prime} \mathrm{E}\right)$, Republic of Korea, using the standard dilution plating technique. Isolation was achieved on marine agar (MA; Difco) (Yang et al., 2006) at $30{ }^{\circ} \mathrm{C}$ for 7 days. The isolate was cultured routinely on MA and maintained at $-80{ }^{\circ} \mathrm{C}$ as a suspension in marine broth ( $\mathrm{MB}$; Difco) containing glycerol $(20 \%, \mathrm{w} / \mathrm{v})$.

Bacterial DNA preparation, PCR amplification and sequencing of the $16 \mathrm{~S}$ rRNA gene were carried out as described previously (Chun \& Goodfellow, 1995). The resulting sequence of strain $\mathrm{C} 4^{\mathrm{T}}$ was aligned manually 
against sequences obtained from GenBank. Phylogenetic trees were inferred from the regions available for all sequences (positions 38-1450; Escherichia coli numbering system) using the Fitch-Margoliash (Fitch \& Margoliash, 1967) and neighbour-joining (Saitou \& Nei, 1987) methods. Evolutionary distance matrices were generated according to Jukes \& Cantor (1969). The resultant neighbour-joining tree topology was evaluated by bootstrap analyses (Felsenstein, 1985) based on 1000 resamplings. Alignment and phylogenetic analyses were carried out using the program JPHYDIT (available at http:// plaza.snu.ac.kr/ jchun/jphydit/) and PAUP 4.0 (Swofford, 1998) as described previously (Chun et al., 2000).
Preliminary sequence comparison with 16S rRNA gene sequences held in GenBank indicated that our isolate was closely related to strains of the genus Shewanella. The newly determined sequence was then aligned manually against representatives of the genus Shewanella. Strain $\mathrm{C}^{\mathrm{T}}$ showed the highest $16 \mathrm{~S}$ rRNA gene sequence similarity to Shewanella waksmanii $\mathrm{KMM} 3823^{\mathrm{T}}$ (96.1\%), followed by Shewanella fidelis KMM $3582^{\mathrm{T}}$ (96.0\%), Shewanella surugensis DSM $17177^{\mathrm{T}}(95.8 \%)$, Shewanella pneumatophori JCM $13187^{\mathrm{T}}$ (95.8\%), Shewanella schlegeliana JCM $11561^{\mathrm{T}}$ (95.7\%), Shewanella haliotis DW01 ${ }^{\mathrm{T}}(95.6 \%)$ and Shewanella algae ATCC $51192^{\mathrm{T}}(95.6 \%)$; similarities to other members of the genus Shewanella were $92.7-95.6 \%$. To elucidate the

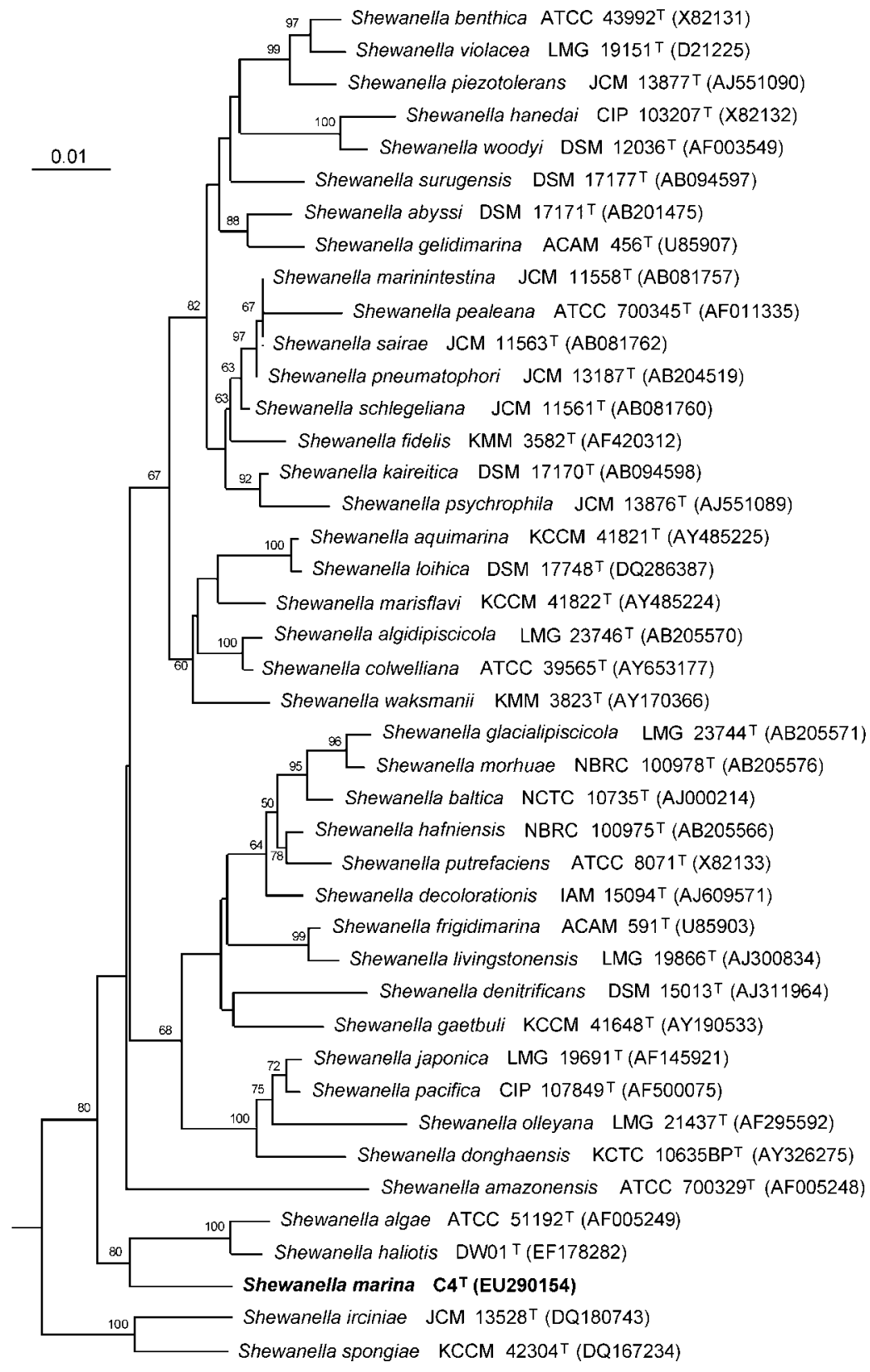

Fig. 1. Neighbour-joining tree based on nearly complete 16S rRNA gene sequences showing relationships between strain $\mathrm{C}^{\top}$ and members of the genus Shewanella. Numbers at nodes are the levels of bootstrap support (\%) based on neighbour-joining analyses of 1000 resampled datasets. The sequence of Vibrio cholerae ATCC $14035^{\top}$ (Z21856) was used as an outgroup (not shown). Bar, $0.01 \mathrm{nt}$ substitutions per position. 
phylogenetic relationship between the novel isolate and other members of the genus Shewanella, phylogenetic trees were constructed using two different tree-making algorithms. The neighbour-joining tree (Fig. 1) showed that strain $\mathrm{C}^{\mathrm{T}}$ formed a distinct branch with the clade comprising S. algae ATCC $51192^{\mathrm{T}}$ and S. haliotis $\mathrm{DW} 01^{\mathrm{T}}$, which was also observed in the Fitch-Margoliash tree (data not shown). On the basis of 16S rRNA gene sequence similarity data and the results of the phylogenetic analysis, it is clear that our isolate represents a novel genomic species within the genus Shewanella (Wayne et al., 1987).

As $16 \mathrm{~S}$ rRNA gene sequence similarities between strain $\mathrm{C} 4{ }^{\mathrm{T}}$ and recognized Shewanella species were below the level indicative of relatedness at the species level (97\%; Stackebrandt \& Goebel, 1994), no DNA-DNA hybridization tests were needed to define a novel species.

Growth on various standard bacteriological media was tested on nutrient agar (NA; Difco), tryptic soy agar (TSA; Difco) and R2A agar (Difco) according to the manufacturer's instructions. Cells grown at $30{ }^{\circ} \mathrm{C}$ for 2 days were observed using a differential interference microscope (BX50; Olympus) and a scanning electron microscope (S4800 ; Hitachi). Cells of strain $\mathrm{C} 4{ }^{\mathrm{T}}$ grown on MA at $30{ }^{\circ} \mathrm{C}$ for 3-7 days were used for physiological and biochemical tests. Motility was examined by observing cells grown in wet mounts using a phase-contrast microscope (DS-Fil; Nikon). The requirement for sea salts (0-10\%; Sigma) for growth was tested using synthetic ZoBell medium (15 g Bacto agar, $5 \mathrm{~g}$ Bacto peptone, $1 \mathrm{~g}$ yeast extract, $0.1 \mathrm{~g}$ ferric citrate in $1 \mathrm{l}$ distilled water). The $\mathrm{pH}$ range for growth was determined in ZoBell medium that was adjusted to various $\mathrm{pH}$ values ( $\mathrm{pH} 3-11$, in increments of $1 \mathrm{pH}$ unit) by the addition of $\mathrm{HCl}$ and $\mathrm{NaOH}$. Growth at various temperatures $\left(4-50{ }^{\circ} \mathrm{C}\right)$ and growth in an anaerobic chamber $\left(\mathrm{CO}_{2} / \mathrm{H}_{2} / \mathrm{N}_{2}, 10: 10: 80\right.$ by vol.; Sheldon Manufacturing) were assessed using MA and incubation times of up to 1 week. Catalase and oxidase activities were determined using 3\%(v/v) hydrogen peroxide and Kovacs' reagent (Kovacs, 1956), respectively. Acid production from glucose was tested as described by Yamaguchi \& Yokoe (2000). Nitrate reduction was tested on $\mathrm{MB}$ containing $0.2 \%$ $\mathrm{KNO}_{3}$ (Skerman, 1967). $\mathrm{H}_{2} \mathrm{~S}$ production was determined on Kligler iron agar (Difco) with $2 \%(\mathrm{w} / \mathrm{v})$ sea salts. Hydrolysis of carboxymethylcellulose $(1 \%, \mathrm{w} / \mathrm{v})$, casein $(2 \%, w / v$, skim milk), egg yolk $(10 \%$, w/v), starch $(0.2 \%$, $\mathrm{w} / \mathrm{v})$ and Tween $80(1 \%, \mathrm{w} / \mathrm{v})$ was tested as described by Smibert \& Krieg (1994) using MA as the basal medium. Hydrolysis of L-tyrosine $(0.5 \%, \mathrm{w} / \mathrm{v})$ and xylan $(1 \%, \mathrm{w} / \mathrm{v})$ was tested using MA as the basal medium (Barrow \& Feltham, 1993). DNase activity was determined with DNase test agar (Difco) containing $2 \%(\mathrm{w} / \mathrm{v})$ sea salts. Other biochemical tests and enzymic activities were performed using API 20E and API ZYM kits (bioMérieux) and the GN2 MicroPlate (Biolog) prepared according to the manufacturer's instructions except that bacterial strains

Table 1. Phenotypic characteristics that differentiate strain $C 4^{\top}$ from type strains of phylogenetically related Shewanella species

Strains: 1, C4 ${ }^{\mathrm{T}}$; 2, S. algae ATCC $51192^{\mathrm{T}}$; 3, S. fidelis KMM $3582^{\mathrm{T}}$; 4, S. haliotis DW01 ${ }^{\mathrm{T}}$; 5, S. waksmanii KMM $3823^{\mathrm{T}}$. Data are from Ivanova et al. (2003a, b), Khashe \& Janda (1998), Kim et al. (2007), Nozue et al. (1992) and this study. All strains are positive for catalase, oxidase, production of $\mathrm{H}_{2} \mathrm{~S}$ and gelatinase. All strains are negative for utilization of citrate and lactose. +, Positive; -, negative; w, weakly positive; ND, no data available; $\mathrm{R}$, resistant; $\mathrm{S}$, sensitive.

\begin{tabular}{|c|c|c|c|c|c|}
\hline Characteristic & 1 & 2 & 3 & 4 & 5 \\
\hline Source & Seawater & Salt marsh & Sediment & Abalone & Sipuncula \\
\hline Colony colour & Pale brown & Pink & Pinkish & Pink-orange & Greenish brown \\
\hline Growth at $4{ }^{\circ} \mathrm{C}$ & + & - & + & - & + \\
\hline Growth at $42{ }^{\circ} \mathrm{C}$ & - & + & - & + & - \\
\hline Arginine dihydrolase & + & - & ND & - & ND \\
\hline Lysine decarboxylase & + & - & ND & - & ND \\
\hline Ornithine decarboxylase & - & + & $\mathrm{ND}$ & + & $\mathrm{ND}$ \\
\hline Acidification of glucose & $\mathrm{W}$ & $\mathrm{W}$ & + & - & + \\
\hline \multicolumn{6}{|l|}{ Assimilation of: } \\
\hline Mannose & - & + & - & - & + \\
\hline Caprate & - & + & ND & + & $\mathrm{ND}$ \\
\hline Malate & - & - & $\mathrm{ND}$ & + & $\mathrm{ND}$ \\
\hline Glucose & - & - & + & - & + \\
\hline Fructose & - & + & - & - & - \\
\hline \multicolumn{6}{|l|}{ Antibiotic resistance } \\
\hline Ampicillin $(10 \mu \mathrm{g})$ & S & $\mathrm{R}^{*}$ & $\mathrm{ND}$ & $\mathrm{R}$ & ND \\
\hline Polymyxin B (300 IU) & S & $S^{*}$ & S & $\mathrm{R}$ & S \\
\hline DNA G $+C$ content $(\mathrm{mol} \%)$ & $40.8 \dagger$ & 54.0 & 45.0 & 53.7 & 43.0 \\
\hline
\end{tabular}

${ }^{\star}$ Data from this study.

$\dagger$ Mean value from two DNA analyses. 
were suspended in distilled water supplemented with $2 \%$ (w/v) sea salts. Antibiotic resistance was determined by the disc diffusion method using commercial antibiotic-impregnated discs (BBL Becton Dickinson). The results were interpreted according to the guidelines set forth by the CLSI (2003).

Cells of strain $\mathrm{C} 4^{\mathrm{T}}$ were facultatively anaerobic, Gramnegative, motile and rod-shaped (Supplementary Fig. S1, available in IJSEM Online). Colonies grown on MA plates for 5 days at $30{ }^{\circ} \mathrm{C}$ were circular, convex with entire margins, smooth, opaque, pale brown in colour and approximately $2.0-3.0 \mathrm{~mm}$ in diameter. The isolate grew well on MA and R2A, but not on TSA or NA. On MA, strain $\mathrm{C} 4^{\mathrm{T}}$ was able to grow at $4-37{ }^{\circ} \mathrm{C}$. Detailed results of physiological and biochemical analyses are given in Table 1 and the species description. It is evident from Table 1 that there are several phenotypic characteristics that readily separate strain $\mathrm{C} 4^{\mathrm{T}}$ from phylogenetically related species.

Cellular fatty acids of strain $\mathrm{C}^{\mathrm{T}}$ grown on MA for 2 days at $30{ }^{\circ} \mathrm{C}$ were prepared (in duplicate) and analysed as methyl esters by GLC according to the instructions of the Microbial Identification system (MIDI). For G + C content calculations, DNA samples were prepared in duplicate and the $\mathrm{G}+\mathrm{C}$ content was determined by using the thermal denaturation method of Marmur \& Doty (1962).

The cellular fatty acid profile of strain $\mathrm{C} 4^{\mathrm{T}}$ is given in Table 2. Significant differences in the contents of predominant fatty acids were found between strain $\mathrm{C} 4^{\mathrm{T}}$ and strains of related species, i.e. summed feature 3 $\left(\mathrm{C}_{16: 1} \omega 7 c\right.$ and/or iso- $\left.\mathrm{C}_{15: 0} 2-\mathrm{OH}\right), \mathrm{C}_{16: 0}$ and iso- $\mathrm{C}_{15: 0}$. The DNA $\mathrm{G}+\mathrm{C}$ content of strain $\mathrm{C}^{\mathrm{T}}$ was $40.8 \pm 0.4 \mathrm{~mol} \%$, which is lower than those of $S$. algae and S. haliotis.

Phylogenetic, genomic, chemotaxonomic and phenotypic data clearly indicate that strain $\mathrm{C}^{\mathrm{T}}$ represents a novel genomic species within the genus Shewanella, for which the name Shewanella marina sp. nov. is proposed.

\section{Description of Shewanella marina sp. nov.}

Shewanella marina (ma.ri'na. L. fem. adj. marina marine, of the sea, where the type strain was isolated).

Cells are rod-shaped, Gram-negative and facultatively anaerobic. Cells grow best on media such as MA and R2A. Colonies on MA are circular, convex with entire margins, smooth, opaque, pale brown in colour and approximately $2.0-3.0 \mathrm{~mm}$ in diameter after 5 days at $30{ }^{\circ} \mathrm{C}(\mathrm{pH} 7)$. Cells are motile rods, $0.4-0.5 \times 1.4-2.0 \mu \mathrm{m}$ in size. Growth occurs in $2-9 \%(\mathrm{w} / \mathrm{v}) \mathrm{NaCl}$ (optimum, $3 \%$ ), at $\mathrm{pH} 5-10$ (optimum, $\mathrm{pH} 7$ ) and at $4-37{ }^{\circ} \mathrm{C}$ (optimum, $30^{\circ} \mathrm{C}$ ). Oxidase- and catalase-positive. Acetoin is produced. Casein, DNA and Tween 80 are hydrolysed, but carboxymethylcellulose, egg yolk, aesculin, starch, tyrosine and xylan are not. In the API ZYM gallery: alkaline phosphatase, acid phosphatase, esterase
Table 2. Cellular fatty acid compositions (\%) of strain $\mathrm{C} 4{ }^{\top}$ and type strains of phylogenetically related Shewanella species

Strains: 1, C4 ${ }^{\mathrm{T}}$; 2, S. algae ATCC $51192^{\mathrm{T}}$; 3, S. fidelis KMM $3582^{\mathrm{T}}$; 4, S. haliotis $\mathrm{DW}_{01}^{\mathrm{T}}$; 5, S. waksmanii $\mathrm{KMM} 3823^{\mathrm{T}}$. Data are from Ivanova et al. (2003a, b), Khashe \& Janda (1998), Kim et al. (2007), Nozue et al. (1992) and this study. -, Fatty acid not present; tr, trace amount $(<1 \%)$.

\begin{tabular}{|c|c|c|c|c|c|}
\hline Fatty acid & $1^{\star}$ & 2 & 3 & 4 & 5 \\
\hline \multicolumn{6}{|c|}{ Straight-chain saturated } \\
\hline $\mathrm{C}_{12: 0}$ & 3.7 & 1.9 & 1.2 & 2.2 & 2.0 \\
\hline $\mathrm{C}_{13: 0}$ & $\operatorname{tr}$ & $\operatorname{tr}$ & 1.5 & $\operatorname{tr}$ & 2.3 \\
\hline $\mathrm{C}_{14: 0}$ & 1.4 & 1.2 & 2.3 & 1.9 & 1.7 \\
\hline $\mathrm{C}_{15: 0}$ & 2.5 & 3.7 & 8.7 & 2.8 & 5.3 \\
\hline $\mathrm{C}_{16: 0}$ & 16.3 & 11.6 & 12.9 & 13.4 & 6.2 \\
\hline $\mathrm{C}_{17: 0}$ & 2.3 & 3.0 & 1.5 & 2.5 & 2.9 \\
\hline $\mathrm{C}_{18: 0}$ & 2.4 & 3.3 & $\operatorname{tr}$ & 6.5 & $\operatorname{tr}$ \\
\hline $\mathrm{C}_{12: 0} 3-\mathrm{OH}$ & 2.0 & 2.4 & - & 2.0 & - \\
\hline \multicolumn{6}{|l|}{ Branched saturated } \\
\hline iso- $\mathrm{C}_{13: 0}$ & 4.4 & 3.3 & 10.7 & 4.1 & 10.3 \\
\hline iso- $\mathrm{C}_{14: 0}$ & 2.0 & $\operatorname{tr}$ & $\operatorname{tr}$ & 1.1 & $\operatorname{tr}$ \\
\hline iso- $\mathrm{C}_{15: 0}$ & 7.7 & 20.7 & 22.3 & 17.7 & 33.4 \\
\hline iso- $\mathrm{C}_{16: 0}$ & $\operatorname{tr}$ & $\operatorname{tr}$ & - & $\operatorname{tr}$ & $\operatorname{tr}$ \\
\hline iso- $\mathrm{C}_{17: 0}$ & $\operatorname{tr}$ & 1.8 & $\operatorname{tr}$ & 1.6 & 4.7 \\
\hline iso- $\mathrm{C}_{13: 0} 3-\mathrm{OH}$ & 1.3 & 2.9 & - & 2.5 & $\operatorname{tr}$ \\
\hline \multicolumn{6}{|l|}{ Monounsaturated } \\
\hline $\mathrm{C}_{15: 1} \omega 6 \mathrm{c}$ & - & - & 1.0 & - & $\operatorname{tr}$ \\
\hline $\mathrm{C}_{16: 1} \omega 7 c$ & - & - & 20.0 & - & 9.8 \\
\hline $\mathrm{C}_{16: 1} \omega 9 c$ & 2.0 & 1.3 & - & 1.1 & - \\
\hline $\mathrm{C}_{17: 1} \omega 6 c$ & $\operatorname{tr}$ & $\operatorname{tr}$ & 1.9 & $\operatorname{tr}$ & 1.2 \\
\hline $\mathrm{C}_{17: 1} \omega 8 c$ & 9.5 & 11.8 & 6.3 & 10.7 & 6.2 \\
\hline $\mathrm{C}_{18: 1} \omega 7 c$ & 5.3 & 4.8 & 5.6 & 5.4 & 2.9 \\
\hline $\mathrm{C}_{18: 1} \omega 9 c$ & 5.1 & 4.1 & $\operatorname{tr}$ & 4.5 & $\operatorname{tr}$ \\
\hline $\mathrm{C}_{20: 5} \omega 3 c$ & - & - & - & - & 6.7 \\
\hline Summed feature $1 \dagger$ & $\operatorname{tr}$ & 1.9 & - & 1.5 & - \\
\hline Summed feature $2 \dagger$ & 2.6 & 1.2 & - & 1.1 & - \\
\hline Summed feature $3 \dagger$ & 19.4 & 13.5 & - & 12.5 & - \\
\hline
\end{tabular}

${ }^{\star}$ Mean values from two determinations.

$\dagger$ Summed features represent groups of two fatty acids that cannot be separated by GLC with the MIDI system. Summed feature 1 contains $\mathrm{C}_{13: 0} 3-\mathrm{OH}$ and/or iso- $\mathrm{C}_{15: 1} \mathrm{I} / \mathrm{H}$. Summed feature 2 contains $\mathrm{C}_{14: 0}$ $3-\mathrm{OH}$ and/or iso- $\mathrm{C}_{16: 1} \mathrm{I}$. Summed feature 3 contains $\mathrm{C}_{16: 1} \omega 7 c$ and/or iso- $\mathrm{C}_{15: 0} 2-\mathrm{OH}$.

(C4), leucine arylamidase, naphthol-AS-BI-phosphohydrolase and trypsin are positive; esterase lipase (C8), cystine arylamidase and valine arylamidase are weakly positive; and $N$-acetyl- $\beta$-glucosaminidase, $\alpha$-chymotrypsin, $\alpha$-fucosidase, $\alpha$-galactosidase, $\beta$-galactosidase, $\alpha$ glucosidase, $\beta$-glucuronidase, $\beta$-glucosidase, lipase (C14) and $\alpha$-mannosidase are negative. The following carbon sources are utilized (positive with the Biolog GN2 system): DL-lactic acid, L-arabinose (weak), D-glucose (weak), L-rhamnose (weak), citric acid (weak), malonic acid (weak), propionic acid (weak), L-alanine (weak), Lalanyl glycine (weak) and $\alpha$-hydroxybutyric acid (weak). 
The remaining substrates of the Biolog GN2 system are not utilized (Supplementary Table S1, available in IJSEM Online). Cells are sensitive to ( $\mu \mathrm{g}$ per disc, unless otherwise indicated) amikacin (30), ampicillin (10), chloramphenicol (30), gentamicin (10), erythromycin (15), kanamycin (30), nalidixic acid (30) and polymyxin B (300 IU), but resistant to penicillin (10 IU), streptomycin (10), tetracycline (30) and vancomycin (30). Other physiological and biochemical characteristics are given in Table 1. Major fatty acids are summed feature 3 $\left(\mathrm{C}_{16: 1} \omega 7 c\right.$ and/or iso- $\left.\mathrm{C}_{15: 0} 2-\mathrm{OH}\right), \mathrm{C}_{16: 0}, \mathrm{C}_{17: 1} \omega 8 c$ and iso- $\mathrm{C}_{15: 0}$; the complete fatty acid composition of the type strain is given in Table 2 .

The type strain, $\mathrm{C}^{\mathrm{T}}\left(=\mathrm{KCTC} 22185^{\mathrm{T}}=\mathrm{JCM} 15074^{\mathrm{T}}\right)$, was isolated from seawater collected from the South Sea, Republic of Korea. The DNA G + C content of the type strain is $40.8 \mathrm{~mol} \%$.

\section{Acknowledgements}

This research was supported by the 21C Frontier Microbial Genomics and Applications Center Program, Ministry of Education, Science \& Technology, Republic of Korea.

\section{References}

Aguirre, A. A., Balazs, G. H., Zimmerman, B. \& Spraker, T. R. (1994). Evaluation of Hawaiian green turtles (Cheledonia mydas) for potential pathogens associated with fibropapillomas. J Wildl Dis 30, 8-15.

Anzai, Y., Kim, H., Park, J. Y., Wakabayashi, H. \& Oyaizu, H. (2000). Phylogenetic affiliation of the pseudomonads based on 16S rRNA sequence. Int J Syst Evol Microbiol 50, 1563-1589.

Barrow, G. I. \& Feltham, R. K. A. (1993). Cowan and Steel's Manual for the Identification of Medical Bacteria, 3rd edn. Cambridge: Cambridge University Press.

Bowman, J. P. (2005). Genus XIII. Shewanella MacDonell and Colwell $1986,355^{\mathrm{VP}}$ (Effective publication: MacDonell and Colwell 1985, 180). In Bergey's Manual of Systematic Bacteriology, 2nd edn, vol. 2, part B, pp. 480-491. Edited by D. J. Brenner, N. R. Krieg, J. T. Staley \& G. M. Garrity. New York: Springer.

Bowman, J. P., McCammon, S. A., Nichols, D. S., Skerratt, J. H., Rea, S. M., Nichols, P. D. \& McMeekin, T. A. (1997). Shewanella gelidimarina sp. nov. and Shewanella frigidimarina sp. nov., novel Antarctic species with the ability to produce eicosapentaenoic acid $(20: 5 \omega 3)$ and grow anaerobically by dissimilatory Fe(III) reduction. Int J Syst Bacteriol 47, 1040-1047.

Bozal, N., Montes, M. J., Tudela, E., Jiménez, F. \& Guinea, J. (2002). Shewanella frigidimarina and Shewanella livingstonensis sp. nov. isolated from Antarctic coastal areas. Int J Syst Evol Microbiol 52, 195-205.

Brettar, I., Christen, R. \& Höfle, M. G. (2002). Shewanella denitrificans sp. nov., a vigorously denitrifying bacterium isolated from the oxicanoxic interface of the Gotland Deep in the central Baltic Sea. Int J Syst Evol Microbiol 52, 2211-2217.

Brink, A. J., van Straten, A. \& van Rensburg, A. J. (1995). Shewanella (Pseudomonas) putrefaciens bacteremia. Clin Infect Dis 20, 1327-1332.

Chun, J. \& Goodfellow, M. (1995). A phylogenetic analysis of the genus Nocardia with $16 \mathrm{~S}$ rRNA gene sequences. Int J Syst Bacteriol 45, 240-245.
Chun, J., Bae, K. S., Moon, E. Y., Jung, S.-O., Lee, H. K. \& Kim, S.-J. (2000). Nocardiopsis kunsanensis sp. nov., a moderately halophilic actinomycete isolated from a saltern. Int J Syst Evol Microbiol 50, 1909-1913.

CLSI (2003). Performance standards for antimicrobial disk susceptibility tests, 8th edn. Approved Standard M2-A8. Wayne, PA: Clinical Laboratory Standards Institute.

Debois, J., Degreef, H., Vandepitte, J. \& Spaepen, J. (1975). Pseudomonas putrefaciens as a cause of infection in humans. J Clin Pathol 28, 993-996.

Felsenstein, J. (1985). Confidence limits on phylogenies: an approach using the bootstrap. Evolution 39, 783-791.

Fitch, W. M. \& Margoliash, E. (1967). Construction of phylogenetic trees. Science 155, 279-284.

Gao, H., Obraztova, A., Stewart, N., Popa, R., Fredrickson, J. K., Tiedje, J. M., Nealson, K. H. \& Zhou, J. (2006). Shewanella loihica sp. nov., isolated from iron-rich microbial mats in the Pacific Ocean. Int J Syst Evol Microbiol 56, 1911-1916.

Gauthier, G., Gauthier, M. \& Christen, R. (1995). Phylogenetic analysis of the genera Alteromonas, Shewanella, and Moritella using genes coding for small-subunit rRNA sequences and division of the genus Alteromonas into two genera, Alteromonas (emended) and Pseudoalteromonas gen. nov., and proposal of twelve new species combinations. Int J Syst Bacteriol 45, 755-761.

Gram, L. \& Huss, H. H. (1996). Microbiological spoilage of fish and fish products. Int J Food Microbiol 33, 121-137.

Gram, L., Trolle, G. \& Huss, H. H. (1987). Detection of specific spoilage bacteria from fish stored at low $\left(0{ }^{\circ} \mathrm{C}\right)$ and high $\left(20^{\circ} \mathrm{C}\right)$ temperatures. Int J Food Microbiol 4, 65-72.

Hirota, K., Nodasaka, Y., Orikasa, Y., Okuyama, H. \& Yumoto, I. (2005). Shewanella pneumatophori sp. nov., an eicosapentaenoic acidproducing marine bacterium isolated from the intestines of Pacific mackerel (Pneumatophorus japonicus). Int J Syst Evol Microbiol 55, 2355-2359.

Holmes, B., Lapage, S. P. \& Malnick, H. (1975). Strains of Pseudomonas putrefaciens from clinical material. J Clin Pathol 28, 149-155.

Ivanova, E. P., Sawabe, T., Gorshkova, N. M., Svetashev, V. I., Mikhailov, V. V., Nicolau, D. V. \& Christen, R. (2001). Shewanella japonica sp. nov. Int J Syst Evol Microbiol 51, 1027-1033.

Ivanova, E. P., Nedashkovskaya, O. I., Zhukova, N. V., Nicolau, D. V., Christen, R. \& Mikhailov, V. V. (2003a). Shewanella waksmanii sp. nov., isolated from a sipuncula (Phascolosoma japonicum). Int J Syst Evol Microbiol 53, 1471-1477.

Ivanova, E. P., Sawabe, T., Hayashi, K., Gorshkova, N. M., Zhukova, N. V., Nedashkovskaya, O. I., Mikhailov, V. V., Nicolau, D. V. \& Christen, R. (2003b). Shewanella fidelis sp. nov., isolated from sediments and sea water. Int J Syst Evol Microbiol 53, 577582.

Ivanova, E. P., Gorshkova, N. M., Bowman, J. P., Lysenko, A. M., Zhukova, N. V., Sergeev, A. F., Mikhailov, V. V. \& Nicolau, D. V. (2004a). Shewanella pacifica sp. nov., a polyunsaturated fatty acidproducing bacterium isolated from sea water. Int J Syst Evol Microbiol 54, 1083-1087.

Ivanova, E. P., Nedashkovskaya, O. I., Sawabe, T., Zhukova, N. V., Frolova, G. M., Nicolau, D. V., Mikhailov, V. V. \& Bowman, J. P. (2004b). Shewanella affinis sp. nov., isolated from marine invertebrates. Int J Syst Evol Microbiol 54, 1089-1093.

Jørgensen, B. R. \& Huss, H. H. (1989). Growth and activity of Shewanella putrefaciens isolated from spoiling fish. Int $J$ Food Microbiol 9, 51-62. 
Jukes, T. H. \& Cantor, C. R. (1969). Evolution of protein molecules. In Mammalian Protein Metabolism, vol. 3, pp. 21-132. Edited by H. N. Munro. New York: Academic Press.

Khashe, S. \& Janda, J. M. (1998). Biochemical and pathogenic properties of Shewanella alga and Shewanella putrefaciens. J Clin Microbiol 36, 783-787.

Kim, D., Baik, K. S., Kim, M. S., Jung, B.-M., Shin, T.-S., Chung, G.-H., Rhee, M. S. \& Seong, C. N. (2007). Shewanella haliotis sp. nov., isolated from the gut microflora of abalone, Haliotis discus hannai. Int J Syst Evol Microbiol 57, 2926-2931.

Kovacs, N. (1956). Identification of Pseudomonas pyocyanea by the oxidase reaction. Nature 178, 703.

Lee, O. O., Lau, S. C. K., Tsoi, M. M. Y., Li, X., Plakhotnikova, I., Dobretsov, S., Wu, M. C. S., Wong, P.-K., Weinbauer, M. \& Qian, P.-Y. (2006). Shewanella irciniae sp. nov., a novel member of the family Shewanellaceae, isolated from the marine sponge Ircinia dendroides in the Bay of Villefranche, Mediterranean Sea. Int J Syst Evol Microbiol 56, 2871-2877.

Leonardo, M. R., Moser, D. P., Barbieri, E., Brantner, C. A., MacGregor, B. J., Paster, B. J., Stackebrandt, E. \& Nealson, K. H. (1999). Shewanella pealeana sp. nov., a member of the microbial community associated with the accessory nidamental gland of the squid Loligo pealei. Int J Syst Bacteriol 49, 1341-1351.

Levin, R. E. (1972). Correlation of DNA base composition and metabolism of Pseudomonas putrefaciens isolates from food, human clinical specimens, and other sources. Antonie van Leeuwenhoek 38, 121-127.

MacDonell, M. T. \& Colwell, R. R. (1985). Phylogeny of the Vibrionaceae, and recommendation for two new genera, Listonella and Shewanella. Syst Appl Microbiol 6, 171-182.

Makemson, J. C., Fulayfil, N. R., Landry, W., Van Ert, L. M., Wimpee, C. F., Widder, E. A. \& Case, J. F. (1997). Shewanella woodyi sp. nov., an exclusively respiratory luminous bacterium isolated from the Alboran Sea. Int J Syst Bacteriol 47, 1034-1039.

Marmur, J. \& Doty, P. (1962). Determination of the base composition of deoxyribonucleic acid from its thermal denaturation temperature. J Mol Biol 5, 109-118.

Miyazaki, M., Nogi, Y., Usami, R. \& Horikoshi, K. (2006). Shewanella surugensis sp. nov., Shewanella kaireitica sp. nov. and Shewanella abyssi sp. nov., isolated from deep-sea sediments of Suruga Bay, Japan. Int J Syst Evol Microbiol 56, 1607-1613.

Myers, C. R. \& Nealson, K. H. (1988). Bacterial manganese reduction and growth with manganese oxide as the sole electron acceptor. Science 240, 1319-1321.

Nealson, K. H., Myers, C. R. \& Wimpee, B. (1991). Isolation and identification of manganese reducing bacteria, and estimates of microbial manganese reducing potential in the Black Sea. Deep Sea Res 38, S907-S920.

Nogi, Y., Kato, C. \& Horikoshi, K. (1998). Taxonomic studies of deepsea barophilic Shewanella strains and description of Shewanella violacea sp. nov. Arch Microbiol 170, 331-338.

Nozue, H., Hayashi, T., Hashimoto, Y., Ezaki, T., Hamasaki, K., Ohwada, K. \& Terawaki, Y. (1992). Isolation and characterization of Shewanella alga from clinical specimens and emendation of the description of S. algae Simidu et al., 1990, 335. Int J Syst Bacteriol 42, 628-634.

Petrovskis, E. A., Vogel, T. M. \& Adriaens, P. (1994). Effects of electron acceptors and donors on transformation of tetrachloromethane by Shewanella putrefaciens MR-1. FEMS Microbiol Lett 121, 357-363.

Russell, N. J. \& Nichols, D. S. (1999). Polyunsaturated fatty acids in marine bacteria - a dogma rewritten. Microbiology 145, 767-779.
Saitou, N. \& Nei, M. (1987). The neighbor-joining method: a new method for reconstructing phylogenetic trees. Mol Biol Evol 4, 406425.

Satomi, M., Oikawa, H. \& Yano, Y. (2003). Shewanella marinintestina sp. nov., Shewanella schlegeliana sp. nov. and Shewanella sairae sp. nov., novel eicosapentaenoic-acid-producing marine bacteria isolated from sea-animal intestines. Int J Syst Evol Microbiol 53, 491-499.

Satomi, M., Vogel, B. F., Gram, L. \& Venkateswaran, K. (2006). Shewanella hafniensis sp. nov. and Shewanella morhuae sp. nov., isolated from marine fish of the Baltic Sea. Int J Syst Evol Microbiol 56, 243-249.

Satomi, M., Vogel, B. F., Venkateswaran, K. \& Gram, L. (2007). Description of Shewanella glacialipiscicola sp. nov. and Shewanella algidipiscicola sp. nov., isolated from marine fish of the Danish Baltic Sea, and proposal that Shewanella affinis is a later heterotypic synonym of Shewanella colwelliana. Int J Syst Evol Microbiol 57, 347352.

Semple, K. M. \& Westlake, D. W. S. (1987). Characterization of ironreducing Alteromonas putrefaciens strains from oil field fluids. Can J Microbiol 35, 925-931.

Simidu, U., Kita-Tsukamoto, K., Yasumoto, T. \& Yotsu, M. (1990). Taxonomy of four marine bacterial strains that produce tetrodotoxin. Int J Syst Bacteriol 40, 331-336.

Skerman, V. B. D. (1967). A Guide to the Identification of the Genera of Bacteria, 2nd edn. Baltimore: Williams \& Wilkins.

Skerratt, J. H., Bowman, J. P. \& Nichols, P. D. (2002). Shewanella olleyana sp. nov., a marine species isolated from a temperate estuary which produces high levels of polyunsaturated fatty acids. Int J Syst Evol Microbiol 52, 2101-2106.

Smibert, R. M. \& Krieg, N. R. (1994). Phenotypic characterization. In Methods for General and Molecular Bacteriology, pp. 607-654. Edited by P. Gerhardt, R. G. E. Murray, W. A. Wood \& N. R. Krieg. Washington, DC: American Society for Microbiology.

Stackebrandt, E. \& Goebel, B. M. (1994). Taxonomic note: a place for DNA-DNA reassociation and $16 \mathrm{~S}$ rRNA sequence analysis in the present species definition in bacteriology. Int J Syst Bacteriol 44, 846849.

Stenström, I. M. \& Molin, G. (1990). Classification of the spoilage flora of fish, with special reference to Shewanella putrefaciens. J Appl Bacteriol 68, 601-618.

Swofford, D. L. (1998). PAUP*: Phylogenetic analysis using parsimony (and other methods), version 4. Sunderland, MA: Sinauer Associates. Toffin, L., Bidault, A., Pignet, P., Tindall, B. J., Slobodkin, A., Kato, C. \& Prieur, D. (2004). Shewanella profunda sp. nov., isolated from deep marine sediment of the Nankai Trough. Int J Syst Evol Microbiol 54, 1943-1949.

Venkateswaran, K., Dollhopf, M. E., Aller, R., Stackebrandt, E. \& Nealson, K. H. (1998). Shewanella amazonensis sp. nov., a novel metal-reducing facultative anaerobe from Amazonian shelf muds. Int J Syst Bacteriol 48, 965-972.

Venkateswaran, K., Moser, D. P., Dollhopf, M. E., Lies, D. P., Saffarini, D. A., MacGregor, B. J., Ringelberg, D. B., White, D. C., Nishijima, M. \& other authors (1999). Polyphasic taxonomy of the genus Shewanella and description of Shewanella oneidensis sp. nov. Int J Syst Bacteriol 49, 705-724.

Wayne, L. G., Brenner, D. J., Colwell, R. R., Grimont, P. A. D., Kandler, O., Krichevsky, M. I., Moore, L. H., Moore, W. E. C., Murray, R. G. E. \& other authors (1987). International Committee on Systematic Bacteriology. Report of the ad hoc committee on reconciliation of approaches to bacterial systematics. Int J Syst Bacteriol 37, 463-464.

Xiao, X., Wang, P., Zeng, X., Bartlett, D. H. \& Wang, F. (2007). Shewanella psychrophila sp. nov. and Shewanella piezotolerans sp. nov., 
isolated from west Pacific deep-sea sediment. Int J Syst Evol Microbiol 57, 60-65.

Xu, M., Guo, J., Cen, Y., Zhong, X., Cao, W. \& Sun, G. (2005). Shewanella decolorationis sp. nov., a dye-decolorizing bacterium isolated from activated sludge of a waste-water treatment plant. Int $J$ Syst Evol Microbiol 55, 363-368.

Yamaguchi, S. \& Yokoe, M. (2000). A novel protein-deamidating enzyme from Chryseobacterium proteolyticum sp. nov., a newly isolated bacterium from soil. Appl Environ Microbiol 66, 3337-3343.

Yang, S.-H., Kwon, K. K., Lee, H.-S. \& Kim, S.-J. (2006). Shewanella spongiae sp. nov., isolated from a marine sponge. Int J Syst Evol Microbiol 56, 2879-2882.

Yang, S.-H., Lee, J.-H., Ryu, J.-S., Kato, C. \& Kim, S.-J. (2007). Shewanella donghaensis sp. nov., a psychrophilic, piezosensitive bacterium producing high levels of polyunsaturated fatty acid, isolated from deep-sea sediments. Int J Syst Evol Microbiol 57, 208-212.

Yoon, J. H., Kang, K. H., Oh, T. K. \& Park, Y. H. (2004a). Shewanella gaetbuli sp. nov., a slight halophile isolated from a tidal flat in Korea. Int J Syst Evol Microbiol 54, 487-491.
Yoon, J. H., Yeo, S. H., Kim, I. G. \& Oh, T. K. (2004b). Shewanella marisflavi sp. nov. and Shewanella aquimarina sp. nov., slightly halophilic organisms isolated from sea water of the Yellow Sea in Korea. Int J Syst Evol Microbiol 54, 2347-2352.

Zhao, J.-S., Manno, D., Beaulieu, C., Paquet, L. \& Hawari, J. (2005). Shewanella sediminis sp. nov., a novel $\mathrm{Na}^{+}$-requiring and hexahydro1,3,5-trinitro-1,3,5-triazine-degrading bacterium from marine sediment. Int J Syst Evol Microbiol 55, 1511-1520.

Zhao, J.-S., Manno, D., Leggiadro, C., O’Neil, D. \& Hawari, J. (2006). Shewanella halifaxensis sp. nov., a novel obligately respiratory and denitrifying psychrophile. Int J Syst Evol Microbiol 56, 205-212.

Zhao, J.-S., Manno, D., Thiboutot, S., Ampleman, G. \& Hawari, J. (2007). Shewanella canadensis sp. nov. and Shewanella atlantica sp. nov., manganese dioxide- and hexahydro-1,3,5-trinitro-1,3,5-triazine-reducing, psychrophilic marine bacteria. Int J Syst Evol Microbiol 57, 2155-2162.

Ziemke, F., Höfle, M. G., Lalucat, J. \& Rosselló-Mora, R. (1998). Reclassification of Shewanella putrefaciens Owen's genomic group II as Shewanella baltica sp. nov. Int J Syst Bacteriol 48, 179-186. 